\title{
Population density, sexual reproduction and diapause in monogonont rotifers: new data for Brachionus and a review
}

\author{
John J. GILBERT \\ Department of Biological Sciences, Dartmouth College, Hanover, New Hampshire, 03755 U.S.A. \\ e-mail address: John.J.Gilbert@Dartmouth.edu
}

\begin{abstract}
Diapausing, fertilized eggs in monogonont rotifers typically are formed after an environmental signal induces amictic females to produce mictic daughters. Mictic females lay haploid eggs that may develop parthenogenetically into males, or that may be fertilized and develop into diapausing, female embryos called resting eggs. Laboratory experiments demonstrate that crowding is the signal for production of mictic females in strains of Brachionus calyciflorus from Texas, Spain and Germany, and in a strain of Brachionus variabilis from Spain. In these experiments, newborn amictic females were cultured singly in large and small volumes to give lowand high-density treatments. Therefore, the induction of mictic females is due exclusively to population density and cannot be attributed to a grouping effect involving some interaction among individuals. B. variabilis is very sensitive to population density; females had to be cultured in $30 \mathrm{ml}$ to prevent appreciable production of mictic daughters. Crowding is now known to be the signal for initiation of sexuality and diapause in four species of Brachionus, two species of Epiphanes, and Rhinoglena frontalis. The chemical that mediates this response somehow influences oocytes in the maternal body cavity to differentiate into mictic females. Aggregation of individuals in natural systems may facilitate the production of mictic females. In some of these rotifers, the response to crowding is suppressed in early generations from the resting egg, assuring that clonal populations will attain higher population densities before committing to sexual reproduction. Fitness benefits of the mictic-female response to crowding, and to other environmental signals in other rotifers (dietary tocopherol, long photoperiod), are discussed.
\end{abstract}

Key words: Brachionus, production of mictic females, resting eggs, life cycle

\section{INTRODUCTION}

In the heterogonic life cycle of monogonont rotifers, diapause follows sexual reproduction and the production of fertilized eggs. Sexual reproduction is initiated when amictic females, which parthenogenetically produce diploid daughters, produce some eggs that develop into mictic females. Mictic females produce haploid eggs that develop into males if unfertilized, or into diapausing female embryos, called resting eggs, if fertilized.

In Brachionus and some other rotifers, it is becoming clear that production of mictic females is induced by crowding, or the attainment of a threshold population density (Gilbert 1992, 2002, 2003a; Schröder \& Gilbert 2004). In B. plicatilis, the crowding signal is a chemical that is released by the rotifers themselves (Hino \& Hirano 1976; Carmona et al. 1993; Stelzer \& Snell 2003), and in B. calyciflorus, the crowding stimulus is taxonomically specific (Gilbert 2003a).

However, the importance of population density for induction of mictic females in Brachionus has been questioned by Pourriot \& Rougier $(1977,1979)$. These authors concluded that grouping, or the number of females living together, can affect the production of mictic females in both $B$. plicatilis and B. calyciflorus, but that density itself is not important. For example, a grouping effect would occur if females cultured singly in a volume of $1 \mathrm{ml}$ produced a significantly different proportion of mictic daughters than females cultured at the same density in groups of 5 in a volume of $5 \mathrm{ml}$.

This paper describes experiments showing that population density induces the production of mictic females in strains of B. calyciflorus from Texas, Germany and Spain, and in a strain of Brachionus variabilis from Spain. In addition, it considers and reviews various aspects of the relationship between population density and diapause in rotifers.

\section{METHODS}

The Texas $B$. calyciflorus came from a temporary pond in the Hueco Tanks Historic Site, El Paso. From a culture sent to the author by Elizabeth J. Walsh, one amictic female was isolated to initiate a clonal population. The German strain of this species was from a temporarily flooded area of the Oder River floodplain near Schwedt (Brandenburg). A clonal population was established from an amictic female hatching from a resting egg in sediment collected by Thomas Schröder. The Spanish strain of this species originated from La Laguna de Almenara, a usually permanent lagoon near the Mediterranean coast about $35 \mathrm{~km}$ north of Valencia. The Spanish B. variabilis came from La Albufera de Valencia, a shallow, permanent lake on the Mediterranean coast about $7 \mathrm{~km}$ south of Valencia. A clonal population of each of these two rotifers was initiated 


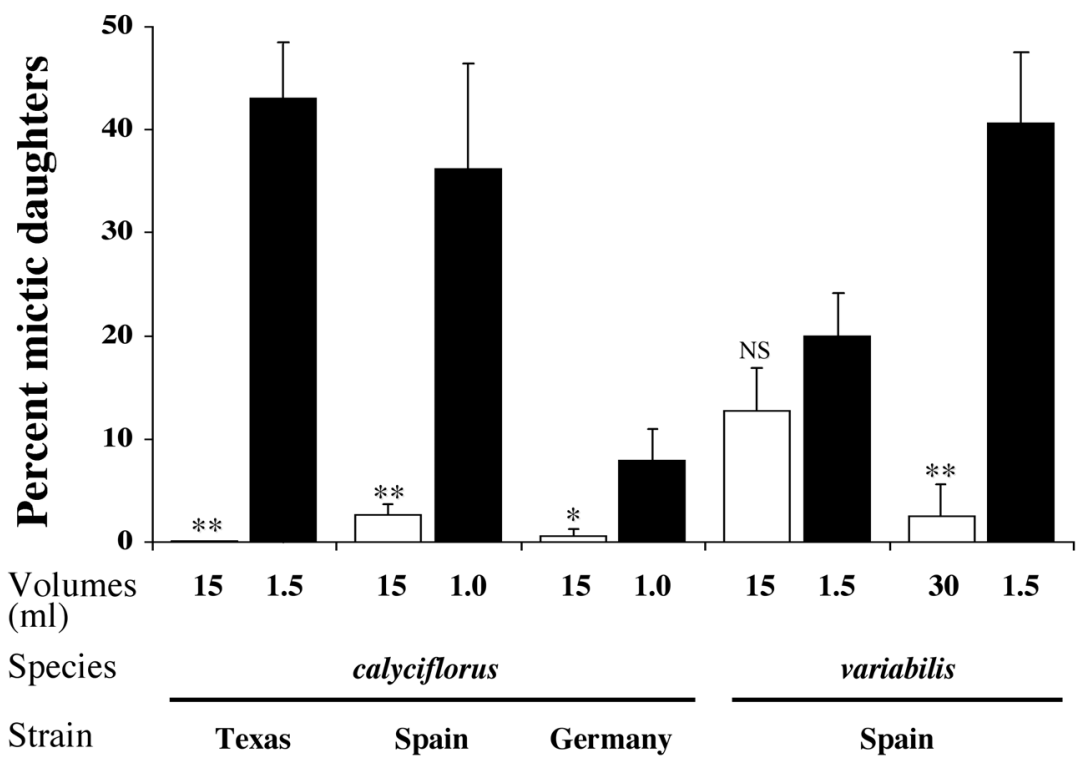

Fig. 1. High population density induces amictic females to produce mictic daughters in three strains of Brachionus calyciflorus (Experiments 1-3) and a strain of Brachionus variabilis (Experiments 4 and 5). Newborn amictic females were cultured singly in large and small volumes to give low- and high-density treatments. See text and tables 1 and 2 for details and statistics. Values are means with $1 \mathrm{SE} ; *$ : $\mathrm{p}<0.05 ; * *: \mathrm{p} \leq 0.0001$.

from an amictic female hatching from a resting egg in dried sediment collected by Manual Serra.

Tab. 1. Details of five experiments testing the effect of population density on mictic-female production in Brachionus calyciflorus and Brachionus variabilis. Dailyrenewed batch cultures were initiated by placing a single newborn female into small $(1.0$ or $1.5 \mathrm{ml})$ or large volumes (15 or $30 \mathrm{ml}$ ). Their offspring were typed as amictic or mictic females.

\begin{tabular}{clccc}
\hline Exp. & Species \& Strain & $\begin{array}{c}\text { Culture vol. n. replicates } \\
(\mathrm{ml})\end{array}$ & $\begin{array}{c}\text { Mean (1 SE) } \\
\text { n. offspring }\end{array}$ \\
\hline \multirow{2}{*}{1} & calyciflorus & 15.0 & 9 & $11.4(0.4)$ \\
& Texas & 1.5 & 12 & $14.2(0.3)$ \\
2 & calyciflorus & 15.0 & 15 & $17.3(0.4)$ \\
& Spain & 1.0 & 11 & $15.9(0.4)$ \\
3 & calyciflorus & 15.0 & 11 & $13.1(1.0)$ \\
& Germany & 1.0 & 10 & $10.7(0.5)$ \\
4 & variabilis & 15.0 & 10 & $6.5(0.8)$ \\
& Spain & 1.5 & 10 & $8.9(0.6)$ \\
5 & variabilis & 30.0 & 10 & $7.2(0.5)$ \\
& Spain & 1.5 & 11 & $6.6(0.6)$ \\
\hline
\end{tabular}

Clonal populations were maintained in MBL medium on Cryptomonas erosa var. reflexa at $20^{\circ} \mathrm{C}$ in a photoperiod (L:D 16:8). To test the effect of population density on the production of mictic females, newborn amictic females were cultured singly in a large volume $(15$ or $30 \mathrm{ml})$ for low-density treatments, and in a small volume $(1$ or $1.5 \mathrm{ml})$ for high-density treatments. The use of single females in these cultures prevented the possibility of confounding density and grouping effects. Culture conditions were MBL medium with $\mathrm{C}$. erosa $\left(2 \times 10^{4}\right.$ cells $\left.\mathrm{ml}^{-1}\right)$ at $20{ }^{\circ} \mathrm{C}$ in a photoperiod (L:D 16:8). In each experiment, 9 to 15 replicate females were used for each treatment. At intervals of 24 $\mathrm{h}$, these females were transferred to fresh conditions, and their daughters were removed and cultured singly in $0.2 \mathrm{ml}$ volumes until they could be typed as amictic or mictic. Further experimental details are presented in table 1 and described elsewhere (Gilbert 2003a). The Mann-Whitney U-test, corrected for ties, was used to compare percentages of mictic daughters produced in low- and high-density treatments.

\section{RESULTS}

The mean number of offspring typed as amictic or mictic females in the two treatments of each experiment are shown in table 1. Experiments 1-3 with $B$. calyciflorus showed that the percentage of mictic daughters was significantly higher in the high-density treatment than in the low-density treatment (Fig. 1; Tab. 2). The propensity to produce mictic daughters was high in the strains from Texas and Spain but low in the one from Germany.

Tab. 2. Mann-Whitney U-tests on percentages of mictic daughters produced in low- and highdensity cultures of Brachionus calyciflorus and B. variabilis (see Tab. 1 and Fig. 1).

\begin{tabular}{ccc}
\hline Experiment & $\mathrm{Z}$ (corrected) & $\mathrm{P}$ \\
\hline 1 & -3.999 & $<.0001$ \\
2 & -4.087 & $<.0001$ \\
3 & -2.208 & .027 \\
4 & -1.108 & .268 \\
5 & -3.817 & .0001 \\
\hline
\end{tabular}

Experiments 4 and 5 with $B$. variabilis showed that single females had to be cultured in a large volume (30 $\mathrm{ml}$ ) to produce a significantly lower percentage of 
Tab. 3. Rotifers in which high population density has been shown to induce the production of mictic females.

\begin{tabular}{lll}
\hline Rotifer & Locations of strain & Reference \\
\hline Brachionus calyciflorus & $\begin{array}{l}\text { Connecticut, Florida, } \\
\text { Georgia, Texas, Spain, } \\
\text { Germany, Australia }\end{array}$ & $\begin{array}{l}\text { Gilbert (1963, 2002, 2003a, } \\
\text { this study) }\end{array}$ \\
B. plicatilis & Japan, Spain, Florida & Hino \& Hirano (1976), \\
& & Carmona et al. (1993), \\
B. angularis & Argentina & Stelzer \& Snell (2003) \\
B. variabilis & Spain & Gilbert (this study) \\
Epiphanes brachionus & France? & Pourriot \& Rougier (1999) \\
E. senta & Germany & Schröder \& Gilbert (2004) \\
Rhinoglena frontalis & Germany & Schöder \& Gilbert (2004) \\
\hline
\end{tabular}

mictic daughters than that produced by females cultured in $1.5 \mathrm{ml}$ (Fig. 1; Tab. 2). When females were cultured in 15 and $1.5 \mathrm{ml}$, the percentages of mictic daughters were similarly high and not significantly different from one another. However, when they were cultured in 30 and $1.5 \mathrm{ml}$, the percentages of mictic daughters were $\mathrm{ca} 3 \%$ and $41 \%$, respectively, and significantly different $(\mathrm{p}=.0001)$.

\section{CONCLUSIONS AND DISCUSSION OF RESULTS}

In all of the Brachionus strains tested, it is clear that high population density is the signal for production of mictic females, and thus the initiation of sexual reproduction and then diapause. Since single females were cultured in large and small volumes to get low- and high-density treatments, this density-dependent response cannot be attributed to a grouping effect. Single individuals probably respond to threshold concentrations of a chemical that they themselves produce. Grouping effects, such as those reported by Pourriot \& Rougier $(1977,1979)$ were not tested. They may be able to affect the response to population density, but they cannot explain the observed responses to population density.

The experiments with $B$. variabilis appear to be the first to examine the effect of an environmental signal on the production of mictic females in this species. They showed that high population density is the signal for this response, and that quite a low density is sufficient to induce mictic females. The rotifer produced a high percentage of mictic daughters even at a low population density ( 1 female in $15 \mathrm{ml}$ ) and had to be cultured at a two-fold lower density ( 1 female in $30 \mathrm{ml}$ ) to prevent appreciable production of mictic daughters. A similarly high sensitivity to population density also was noted for a strain of B. calyciflorus from Australia (Gilbert 2003a), now known to be a different, cryptic species (Gilbert \& Walsh, in press).

The great sensitivity of some Brachionus to population density may explain why Pourriot \& Rougier (1977) found no density effect in B. calyciflorus. The densities they used ranged from 0.2 to 2 females per $\mathrm{ml}$, and percentages of mictic daughters were high $(>40 \%)$ at all densities. If lower population densities had been tested, lower percentages of mictic daughters might have been observed.

\section{GENERAL DISCUSSSION AND REVIEW}

Induction of mictic females by high population density has now been demonstrated in a total of four species of Brachionus, two species of Epiphanes and one species of Rhinoglena (Tab. 3). Density treatments employing single females, and thus avoiding a potential grouping effect, were used for all seven strains of $B$. calyciflorus, one strain each of $B$. variabilis and $B$. angularis, and two strains each of Epiphanes senta and Rhinoglena frontalis.

In all of these experiments, high population density or crowding induces only some percentage of the eggs of amictic females to develop into mictic females. This incomplete response, or bet-hedging strategy, permits a population to continue to grow via female parthenogenesis if the environment remains favorable while it is producing diapausing eggs for a sediment egg bank (Gilbert 2003b).

Induction of mictic females in response to high population density probably is mediated by a chemical released into the environment by the rotifers themselves. However, to date, this has been demonstrated only in B. plicatilis (Hino \& Hirano 1976; Carmona et al. 1993; Stelzer \& Snell 2003). Nothing is known about the identity and lability of the chemical, the rate at which amictic and mictic females release the chemical, or the effect of female age and condition on the rate of release of the chemical. The taxonomic specificity of the crowding effect, and hence the crowding chemical, appears to be low in B. plicatilis (Carmona et al. 1993) but high in B. calyciflorus (Gilbert 2003a). A strain of $B$. calyciflorus from Australia - now known to be a separate, cryptic species (Gilbert \& Walsh, in press) - did not induce production of mictic females in strains of B. calyciflorus from Florida or Georgia.

Pathways by which the crowding chemical may induce amictic females to produce mictic daughters have been considered but are not known (Gilbert 2003b). 
Crowding can affect the fate of females only when the oocytes from which they develop are still within the maternal body cavity. Once eggs are oviposited in the single-cell stage, their fate is already determined. Thus, the crowding chemical could either directly affect some oocytes inside the mother or else target a maternal tissue, possibly the nervous system, which then stimulates some oocytes to differentiate into mictic females.

Rotifer population densities that induce production of mictic females in laboratory experiments may be difficult to relate to natural populations. Natural zooplankton populations can exhibit a highly aggregated dispersion pattern due to responses of individuals to factors such as light, predators and food; so that densities experienced by individuals may be much greater than mean densities (Folt \& Schulze 1993; Folt et al. 1993; Folt \& Burns 1999; Hembre \& Megard 2003). For example, B. calyciflorus is phototactic (Mimouni et al. 1993) and can orient to light in laboratory vessels to form very dense aggregations (Gilbert, unpublished). Similarly, this rotifer swims more slowly and turns more often in response to food (Charoy \& Clément 1993), suggesting that it may aggregate at food patches. Therefore, in natural systems in which overall mean rotifer densities are below a threshold for inducing mictic females, even temporary aggregations may be sufficient to exceed this threshold and trigger initiation of sexual reproduction and diapause.

Attainment of a threshold population density for production of mictic females may cue optimal conditions for production of fertilized, diapausing eggs (Gilbert 1993; Gilbert \& Schröder 2004). Environmental and dietary conditions at this time have proven favorable for population growth and should permit the production of energy-rich resting eggs by fertilized mictic females. Association of sexual reproduction with a high population density also assures large numbers of encounters between males and young, fertilizable mictic females and should maximize the number of resting eggs produced for a sediment egg bank, especially if the crowding stimulus is taxonomically specific (Gilbert 2003a).

In some rotifers, the timing of sexual reproduction and diapause initiation is controlled by an endogenous, generational factor as well as by crowding (Gilbert 2002; Schröder \& Gilbert 2004). Stem females that hatch from resting eggs, and also females produced in the next several parthenogenetic generations, have a significantly lower propensity to respond to crowding than females from later parthenogenetic generations. This transgenerational phenotypic plasticity means that production of mictic females in an inducing environment will be delayed or sub-maximal until population growth via female parthenogenesis continues for additional generations, and hence when population density is higher. This delay should be beneficial to multiclonal populations of a species if the crowding signal was not taxonomically specific, and to clonal populations developing from stem females hatching into highdensity populations established by other clones of the species (Gilbert 2002). The mechanistic basis for the suppressed response to crowding is not understood, but may be caused by an inhibitor in the resting egg and stem female that is gradually diluted in successive parthenogenetic generations (Gilbert 2002, 2003b).

In other rotifers, crowding is not the primary environmental signal for production of mictic females. Dietary tocopherol is the prerequisite signal in four species of Asplanchna (Gilbert \& Thompson 1968; Gilbert 1980, 1992; Gilbert \& Confer 1986), and long photoperiod is the cue in Notommata and Trichocerca (Pourriot 1963; Pourriot \& Clément 1975). However, in Asplanchna brightwelli and Asplanchna sieboldi, high population density - mediated by a chemical released by the rotifers - does increase the response to dietary tocopherol (Birky 1969). This synergistic effect should favor the association between sexual reproduction and crowding so pronounced in Brachionus. Population density also affects the response of Notommata copeus to long photoperiod, but in this case increasing population density decreases the response (Clément \& Pourriot 1973a, b).

It is interesting that the environmental signal for induction of mictic females varies among rotifers. What ecological factors explain the evolution of responses to crowding in Brachionus, Epiphanes and Rhinoglena, to dietary tocopherol in Asplanchna, and to long photoperiod in Notommata and Trichocerca? Speculation on this subject (Gilbert 1974, 1980, 1993) has suggested that the different signals reflect different population dynamics of the rotifers and best indicate environments likely to be suitable for population growth and production of large numbers of fertilized, diapausing eggs.

\section{ACKNOWLEDGMENTS}

The author thanks Manuel Serra for sediment from La Laguna de Almenara and La Albufera de Valencia, Thomas Schröder for sediment from the Oder River floodplain, and Elizabeth J. Walsh for a culture of the Texas B. calyciflorus. He also is most grateful to Victor Alexeev for the invitation to participate in this symposium on diapause.

\section{REFERENCES}

Birky, C.W., Jr. 1969. The developmental genetics of polymorphism in the rotifer Asplanchna. III. Quantitative modification of developmental responses to vitamin E, by the genome, physiological state, and population density of responding females. J. Exp. Zool., 170: 437-448.

Carmona, M.J., M. Serra \& M.R. Miracle. 1993. Relationships between mixis in Brachionus plicatilis and preconditioning of culture medium by crowding. Hydrobiologia, 255/256: 145-152.

Charoy, C. \& P. Clément. 1993. Foraging behaviour of Brachionus calyciflorus (Pallas): variations in the swim- 
ming path according to presence or absence of algal food (Chlorella). Hydrobiologia, 255/256: 95-100.

Clément, P. \& R. Pourriot. 1973. Influence de la densité de population sur la production de femelles mictiques induites par la photopériode chez Notommata copeus (Rotifère). C.R. Acad. Sci., Paris, 276: 3151-3154.

Folt, C.L. \& C.W. Burns. 1999. Biological drivers of zooplankton patchiness. TREE, 14: 300-305.

Folt, C.L. \& P.C. Schulze. 1993. Spatial patchiness, individual performance and predator impacts. Oikos, 68: 560-566.

Folt, C.L., P.C. Schulze \& K. Baumgartner. 1993. Characterizing a zooplankton neighborhood: small-scale patterns of association and abundance. Freshwat. Biol., 30: 289-300.

Gilbert, J.J. 1963. Mictic female production in the rotifer Brachionus calyciflorus. J. Exp. Zool., 153: 113-124.

Gilbert, J.J. 1974. Dormancy in rotifers. Trans. Am. Micros. Soc., 93: 490-513.

Gilbert, J.J. 1980. Female polymorphism and sexual reproduction in the rotifer Asplanchna: evolution of their relationship and control by dietary tocopherol. Am. Nat., 116: 409-431.

Gilbert, J.J. 1992. Rotifera. In: Adiyodi, K.G. \& R.G. Adiyodi (Eds), Reproductive biology of invertebrates. Vol. V. Sexual differentiation and behaviour. Oxford and IBH Publishing Co., New Delhi: 115-136.

Gilbert, J.J. 1993. Rotifera. In: Adiyodi, K.G. \& R.G. Adiyodi (Eds), Reproductive biology of invertebrates. Vol. VI, Part A. Asexual propagation and reproductive strategies. Oxford and IBH Publishing Co., New Delhi: 231-263.

Gilbert, J.J. 2002. Endogenous regulation of environmentally-induced sexuality in a rotifer: a multigenerational parental effect induced by fertilization. Freshwat. Biol., 47: 1633-1641.

Gilbert, J.J. 2003a. Specificity of the crowding response that induces sexuality in the rotifer Brachionus. Limnol. Oceanogr., 48: 1297-1303.

Gilbert, J.J. 2003b. Environmental and endogenous control of sexuality in a rotifer life cycle: developmental and population ecology. Evo. Dev., 5: 19-24.

Gilbert, J.J. \& J.L. Confer. 1986. Gigantism and the potential for interference competition in the rotifer genus $A s$ planchna. Oecologia, 70: 549-554.
Gilbert, J.J. \& T. Schröder. 2004. Rotifers from diapausing, fertilized eggs: unique features and emergence. Limnol. Oceanogr., 49: 1341-1354.

Gilbert, J.J. \& G.A. Thompson, Jr. 1968. Alpha-tocopherol control of sexuality and polymorphism in the rotifer Asplanchna. Science, 159: 734-736.

Hembre, L.K. \& R.O. Megard. 2003. Seasonal and diel patchiness of a Daphnia population: an acoustic analysis. Limnol. Oceanogr., 48: 2221-2233.

Hino, A. \& R. Hirano. 1976. Ecological studies on the mechanism of bisexual reproduction in the rotifer Brachionus plicatilis - I. General aspects of bisexual reproduction inducing factors. Bull. Jap. Soc. Sci. Fish., 42: 1093-1099.

Mimouni, P., A. Luciani \& P. Clément. 1993. How females of the rotifer Asplanchna brightwelli swim in darkness and light: an automated tracking study. Hydrobiologia, 255/256: 101-108.

Pourriot, R. 1963. Influence du rythme nycthéméral sur le cycle sexuel de quelques Rotifères. C.R. Acad. Sci. Paris, 256: 5216-5219.

Pourriot, R. \& C. Rougier. 1977. Effets de la densité de population et du groupement sur la reproduction de Brachionus calyciflorus (Pallas) [Rotifère]. Annls Limnol., 13: 101-113.

Pourriot, R. \& C. Rougier. 1979. Influences conjuguées du groupement et de la qualité de la nourriture sur la reproduction de Brachionus plicatilis O.F. Müller (Rotifère). Neth. J. Zool., 29: 242-2264.

Pourriot, R. \& C. Rougier. 1999. Température, démographie et mixis chez un rotifère héléoplanctonique, Epiphanes brachionus (Ehrb.). Annls Limnol., 35: 167-172.

Schröder, T. \& J.J. Gilbert. 2004. Transgenerational plasticity for sexual reproduction and diapause in the life cycle of monogonont rotifers: intraclonal, intraspecific and interspecific variation in the response to crowding. Funct. Ecol., 18: 458-466.

Stelzer, C.P. \& T.W. Snell. 2003. Induction of sexual reproduction in Brachionus plicatilis (Monogononta, Rotifera) by a density-dependent chemical cue. Limnol. Oceanogr., 48: 939-943. 